\title{
Quantitative Entropy Weight TOPSIS Evaluation of Sustainable Chinese Wind Power Developments
}

\author{
Hongyan Zheng, ${ }^{1,2}$ Dongyang Si, ${ }^{1}$ Wei Wang $\mathbb{D}^{3}{ }^{3}$ and Ruining Wang ${ }^{1}$ \\ ${ }^{1}$ Business School, Sichuan University, Chengdu, China \\ ${ }^{2}$ Institute For Disaster Management and Reconstruction, Sichuan University-The Hong Kong Polytechnic University, Chengdu, China \\ ${ }^{3}$ College of Harbor, Coastal and Offshore Engineering, Hohai University, Nanjing, China
}

Correspondence should be addressed to Wei Wang; 13813826667@hhu.edu.cn

Received 18 April 2018; Revised 13 July 2018; Accepted 30 July 2018; Published 30 September 2018

Academic Editor: Gilberto Espinosa-Paredes

Copyright (C) 2018 Hongyan Zheng et al. This is an open access article distributed under the Creative Commons Attribution License, which permits unrestricted use, distribution, and reproduction in any medium, provided the original work is properly cited.

\begin{abstract}
Based on a Driving Forces-Pressure-State-Impact-Response (DPSIR) model, this paper takes a macroenvironmental, socioeconomic perspective to build an evaluation model to address sustainable Chinese wind power developments and to quantize the development results. From a combination of entropy weight and the Technique for Order of Preference by Similarity to Ideal Solution (TOPSIS) method, the sustainable wind power development level in China is examined, the development trends analyzed, and the trends and underlying laws identified, all of which provides new information for Chinese wind power sustainability. It was found that Chinese sustainable socioeconomic wind power development has been growing year on year. However, the wind power ecological sustainability fell and then rose slowly, indicating that these subsystems both influence the sustainable development of wind power.
\end{abstract}

\section{Introduction}

Since the 1992 United Nations Rio Earth summit, sustainable development has been on the agenda in many developed and developing countries (agenda of the 21st century) [1]. It has led to increased developments in the search for clean energy sources, of which wind power has been one of the strongest contenders, with significant commercialization having taken place in the past 25 years. Because wind power is renewable, endless, nonpolluting, safe, and reliable, many countries have invested heavily in its development [2]. What is more, wind power has more development potential than hydropower, and costs have closer to traditional resources than solar PV [3]. In recent years, China has also been establishing numerous wind power projects around the country. The proportion of China's annual new installation of wind power machines to the world's yearly increased ones raised from less than $10 \%$ in 2006 to $49 \%$ in 2010 . At the end of 2010 , accumulative wind power integration had reached 31 million kilowatts [4], and, in 2011, China replaced the US as the world leader in wind power integration. However, as wind power project investment has increased, wind power curtailment problems have commensurately increased. National Energy Administration data from 2015 indicated that the national wind curtailment ratio had reached $15 \%$. It had risen to 49.7 billion kilowatt hours, with the power provided having reached 33.9 billion kilowatt hours. Wind power curtailment in the Chinese wind power system has been primarily concentrated in three northern regions, all of which have rich traditional wind sources and centralized installed capacity. Of these, Jilin, Inner Mongolia, and Gansu Provinces have the most centralized wind power curtailment, with curtailment rates reaching as high as $40 \%$, indicating the problems with the recycling of renewable energy. What is more, to date in China, coal has been the primary energy source [5], which has resulted in a heavy pollution burden from sulfur dioxide, dust, carbon dioxide, and other greenhouse gases. These have put significant pressure on the eco-environment. Therefore, to ensure sustainable wind power project developments and efficient wind power utilization, it is necessary to evaluate the means by which wind power can be sustainably developed. 


\section{Literature Review}

International research on the evaluation of sustainable development has resulted in the development of complete evaluation systems. The United Nations Commission on Sustainable Development (UNCSD) and the International Federation of Consulting Engineers (FIDIC) both established quantized systems for sustainable development based on the 1992 Rio Earth Summit Agenda for the 21st century, which encompassed social (SO), environmental (EN), and economic (EC) sustainability. Since that time, there has been significant research focused on the development of a basic sustainability evaluation system. Based on this basic framework, this paper examines the current wind power project developments in China to identify the elements associated with comprehensiveness, availability, and quantification principles and then integrates these elements into a sustainable wind power development evaluation index system that includes social, environmental, and economic considerations [6]. Wind power projects have been evaluated from risk, finance, and society, with risk evaluations being the most examined. Based on an adaptive fuzzy neural network, Pinson and Kariniotakis constructed an advanced wind forecast system to predict the online risks of wind farms due to inaccurate weather forecasts [7]. Deng et al. examined multiperiod probability power system risk evaluations in uncertain wind power environments and built a tool to evaluate the power grid safety risks of short period wind power [8]. Based on triangular fuzzy numbers, Li and Sun proposed a fuzzy analytic network process to build a risk evaluation index system for assessing the risks of maritime wind power projects and then demonstrated its viability on a run-time risk evaluation during the construction of a maritime wind farm in Hangzhou Bay [9]. Cheng et al. considered wind speed randomness, fan operating conditions, and wind farm malfunctions to develop a wind farm transmission system risk evaluation method using a Monte Carlo algorithm based on scattered sampling [10]. Based on a financial index to guide company investment and development, financial wind power project evaluations have generally focused on economic evaluations. Salles, Melo, and Legey considered the influence of wind speed on wind power project financial evaluations using a Monte Carlo analysis and a Box and Jenkins (B\&J) model, which was then applied to a wind speed sequence sample from Brazil [11]. Zhan conducted a wind power construction project financial evaluation using the basic data and wind project cardinality from an investment example, to analyze the financial feasibility from profitability, debt paying ability, and uncertainty perspectives [12]. The noneconomic aspects of wind power projects have also attracted research attention. Shiau and Chuen-Yu built an influence index to evaluate the social sustainability of offshore wind power farms by analyzing the Internet process using Dempster-Shafer theory and using a case study from an offshore project in Taiwan [13]. Using fuzzy theory, Yan, $\mathrm{Xu}$, and We built a multihierarchical fuzzy comprehensive evaluation model for the social evaluation of wind power projects that encompassed the socioeconomic environment and the ecological environment [1]. However, while there has been significant wind power project evaluation research, most have only examined evaluations associated with risk, finance, society, or other singular aspects. That is, a complete, scientific wind power sustainability evaluation system has not yet been developed. Therefore, to address this research gap, this paper seeks to develop an overall wind power sustainability evaluation system.

Developing a wind power sustainable development evaluation index system is relatively complicated. Therefore, to establish a suitable index, the Driving Force-PressureSituation- Influence-Response (DPSIR) model developed by the Organization for Economic Cooperation and Development (OECD) in 1993 was used as the basis for refining the sustainable wind power development subsystem [14]. The DPSIR model has been widely used in research into environmental problems and has also been widely applied to sustainability research [15]. In this paper, the DPSIR model is expanded to develop a novel index system design for the sustainable development of the wind power and socioeconomic subsystems to reasonably assess the causal and effective logic of the internal Chinese sustainable wind power development systems, which is the second innovation of this paper. The third innovation in this paper is the quantitative evaluation of Chinese sustainable wind power developments using an entropy weight TOPSIS method, in which the data is first pretreated using mean square error, after which the entropy weight is employed to confirm the weight of each index coefficient and the Technique for Order of Preference by Similarity to Ideal Solution (TOPSIS) method is used to determine the compactness of the treated data to achieve the final evaluation results.

When building the sustainable wind power development evaluation system, this paper takes the wind power energy development challenges into consideration and provides a full scale quantitative evaluation. The establishment of the comprehensive index system can be of reference value to decision-makers and the public, so that they can clearly understand the future direction of the wind power industry in China.

\section{Model Analysis}

Sustainability is related to the organic coordination of environmental, social, and economic benefits. Therefore, an evaluation index needs to include elements such as population growth, economic development, societal changes, energy demand, and ecological and environmental protection [1618]. The sustainable development framework developed by the Commission on Sustainable Development (CSD) and the Fédération lnternationale Des lngénieurs Conseils (FIDIC) are employed to divide the sustainable wind power development system into two key subsystems: a sustainable ecological environmental wind power development subsystem and a sustainable socioeconomic wind power development subsystem.

The sustainable ecological environmental wind power development subsystem refers to the coordination of energy and information to ensure and protect the energy supply 


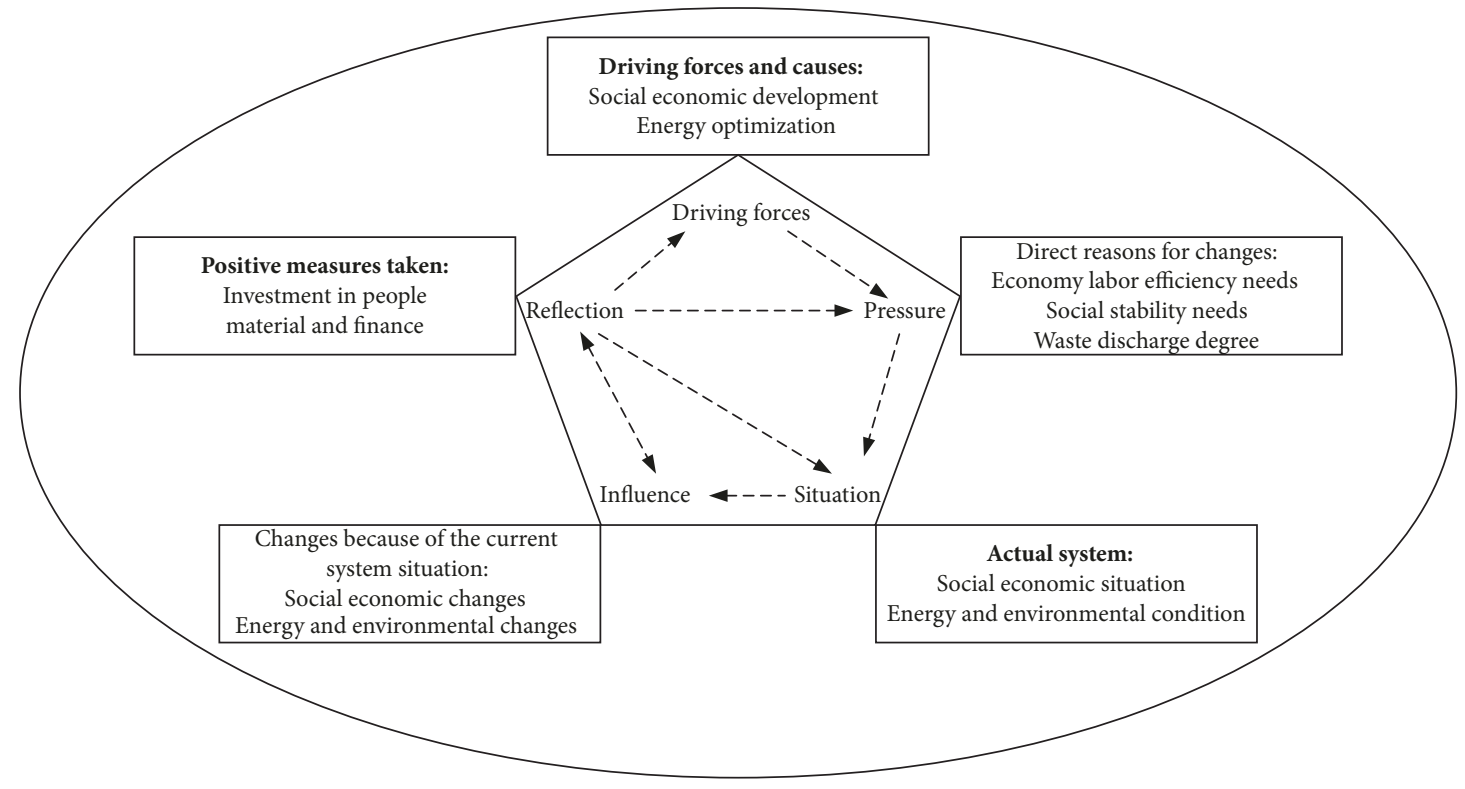

Figure 1: Index function sketch.

and is a precondition for any socioeconomic benefits. The sustainable development of the wind power socioeconomic subsystem requires social protection for the environmental subsystem as any changes in the environmental subsystem can influence the socioeconomic subsystem synergy. As the ecological environment improves, socioeconomic benefits improve. Conversely, when the ecological environment worsens, the socioeconomic benefits are restricted or contained.

As this paper focuses on global subsystem features and critical behavioral information criteria, the DPSIR model is employed to refine the sustainable environmental wind power development subsystem and the sustainable socioeconomic wind power development subsystem, for ensuring that all elements are fully considered.

As shown in Figure 1, as driving forces can affect sustainable development, including the natural driving forces and the socioeconomic driving forces such as resource optimization and the pressure from human activities on the ecological environment, these influences need to be considered to understand the influences on any changes in conditions. Therefore, reflection is necessary to enact positive policies for accelerating the sustainable development process, such as improving resource efficiency, optimizing energy use, reducing pollution, and increasing investment $[19,20]$.

As mentioned, the DPSIR model was used to refine the environmental and socioeconomic subsystems. Their interdependence and interactions are highlighted, and the causality within the inner subsystems is effectively identified.

\section{Building the Index System}

Based on previous research, sustainable wind power development models, and the principles of simplicity, operability, correlation, reference, and innovation, 39 indices were identified. These indices were easy to quantize and had rich connotations, so, from that, the evaluation index system for sustainable wind power development was built, as shown in Table 1.

The evaluation system has a goal layer, a restricted layer, a criterion layer, and an index layer. The goal layer reflects the overall development level of Chinese sustainable wind power developments. The restricted layer includes the basic index system principles and consists of a module layer based on the two-part system structure of the Chinese sustainable environmental wind power development subsystem and the Chinese sustainable socioeconomic wind power development subsystem. The criterion layer refines the subsystems based on the five DPSIR model dimensions, and the index layer contains the all-round indices based on each system index, for which 39 indices are selected.

In the sustainable environmental wind power development subsystem, the driving forces reflect the environmental needs and the energy optimization needs. The gross national energy represents the national energy needs, and the national nonfossil fuel energy of primary energy consumption represents the clean energy proportion. These two indices reflect the environmental driving forces required for sustainable wind power industry development. The pressure is the environmental pressure arising from air pollution sources such as the national carbon dioxide and sulfur dioxide emissions pressure. To effectively reduce greenhouse gas emissions and protect the ecology, this index represents a potential reason for the need to work towards sustainable wind power development. Therefore, the situation is reflected in the occurring problems because of possible climate change effects, as well as the basic wind power resource status. The degree of richness and technical development is reflected in the gross national evaluated wind power energy and the gross national developable wind power energy. The influence is reflected in the influence the wind power industry has 
TABLE 1: The evaluation index system for sustainable wind power development.

\begin{tabular}{|c|c|c|c|c|}
\hline Goal layer & Restricted layer & $\begin{array}{c}\text { Criterion } \\
\text { layer }\end{array}$ & Index layer & Unit \\
\hline \multirow{39}{*}{$\begin{array}{l}\text { Chinese } \\
\text { sustainable wind } \\
\text { power } \\
\text { development } \\
\text { evaluation } \\
\text { system }\end{array}$} & \multirow{16}{*}{$\begin{array}{l}\text { Sustainable } \\
\text { ecological } \\
\text { environmental } \\
\text { evaluation } \\
\text { system }\end{array}$} & $\begin{array}{l}\text { Driving } \\
\text { forces }\end{array}$ & $\begin{array}{l}\text { National non-fossil fuel energy consumption accounts for primary } \\
\text { energy } D_{11}\end{array}$ & $\%$ \\
\hline & & $\mathrm{D}_{1}$ & National energy consumption $\mathrm{D}_{12}$ & $\times 10^{4} \mathrm{t}$ \\
\hline & & \multirow{4}{*}{$\begin{array}{l}\text { Pressure } \\
\mathrm{P}_{1}\end{array}$} & National carbon dioxide emissions $\mathrm{P}_{11}$ & $\times 10^{6} \mathrm{t}$ \\
\hline & & & National sulfur dioxide emissions $\mathrm{P}_{12}$ & $\times 10^{4} \mathrm{t}$ \\
\hline & & & National waste water emissions $\mathrm{P}_{13}$ & $\times 10^{4} \mathrm{t}$ \\
\hline & & & National oxynitride emissions $\mathrm{P}_{14}$ & $\times 10^{4} \mathrm{t}$ \\
\hline & & \multirow{4}{*}{$\begin{array}{l}\text { Situation } \\
\quad \mathrm{S}_{1}\end{array}$} & Gross evaluated national wind power energy $S_{11}$ & $\mathrm{w} / \mathrm{m}^{2}$ \\
\hline & & & Gross developable national wind power energy $S_{12}$ & $\mathrm{~m} / \mathrm{s}$ \\
\hline & & & National annual average temperature $\mathrm{S}_{13}$ & ${ }^{\circ} \mathrm{C}$ \\
\hline & & & National annual average precipitation $\mathrm{S}_{14}$ & $\times 10^{8} \mathrm{~m}^{3}$ \\
\hline & & \multirow{6}{*}{$\begin{array}{l}\text { Influence } \\
\qquad \mathrm{I}_{1}\end{array}$} & National annual average humidity $S_{15}$ & $\%$ \\
\hline & & & $\begin{array}{l}\text { National wind power industry carbon dioxide emissions reductions } \\
\qquad \mathrm{I}_{11}\end{array}$ & $\times 10^{4} \mathrm{t}$ \\
\hline & & & National wind power industry sulfur dioxide emission reductions $I_{12}$ & $\times 10^{4} \mathrm{t}$ \\
\hline & & & National wind power industry nitrogen oxide emission reductions $\mathrm{I}_{13}$ & $\times 10^{4} \mathrm{t}$ \\
\hline & & & National wind power industry water resources saved $\mathrm{I}_{14}$ & $\times 10^{8} \mathrm{~m}^{3}$ \\
\hline & & & $\begin{array}{l}\text { National wind power industry energy consumption reductions (coal) } \\
\qquad \mathrm{I}_{15}\end{array}$ & $\times 10^{4} \mathrm{t}$ \\
\hline & \multirow{23}{*}{$\begin{array}{c}\text { Sustainable } \\
\text { socio-economic } \\
\text { evaluation } \\
\text { system }\end{array}$} & \multirow{3}{*}{ Reflection $\mathrm{R}_{1}$} & National total environmental protection investment $R_{11}$ & $\times 10^{8} \mathrm{RMB}$ \\
\hline & & & Total national investment in clean energy $\mathrm{R}_{12}$ & $\times 10^{8} \mathrm{USD}$ \\
\hline & & & National environmental investment accounts for GDP $R_{13}$ & $\%$ \\
\hline & & \multirow{3}{*}{$\begin{array}{l}\text { Driving } \\
\text { forces } \\
\mathrm{D}_{2}\end{array}$} & National population $\mathrm{D}_{21}$ & $\times 10^{4}$ people \\
\hline & & & National GDP per capita $\mathrm{D}_{22}$ & $\mathrm{RMB}$ \\
\hline & & & National electricity consumption $\mathrm{D}_{23}$ & $\times 10^{8} \mathrm{kwh}$ \\
\hline & & \multirow{3}{*}{$\begin{array}{l}\text { Pressure } \\
\quad \mathrm{P}_{2}\end{array}$} & National average wind abandoned ratio $\mathrm{P}_{21}$ & $\%$ \\
\hline & & & National electricity accidents $\mathrm{P}_{22}$ & time \\
\hline & & & National wind turbines offline time $\mathrm{P}_{23}$ & time \\
\hline & & \multirow{4}{*}{$\begin{array}{l}\text { Situation } \\
\qquad \mathrm{S}_{2}\end{array}$} & National wind power industry installed capacity $S_{21}$ & $\times 10^{4} \mathrm{kwh}$ \\
\hline & & & National wind power generating capacity $S_{22}$ & $\times 10^{4} \mathrm{kwh}$ \\
\hline & & & $\begin{array}{l}\text { National wind power industry's generating capacity accounts for the } \\
\text { whole } S_{23}\end{array}$ & $\%$ \\
\hline & & & Wind power equipment average available hours $\mathrm{S}_{24}$ & hour \\
\hline & & \multirow{7}{*}{$\begin{array}{l}\text { Influence } \\
\qquad \mathrm{I}_{2}\end{array}$} & National wind power integration ratio $S_{25}$ & $\%$ \\
\hline & & & National abandoned wind electricity $\mathrm{I}_{21}$ & $\times 10^{8} \mathrm{kwh}$ \\
\hline & & & National abandoned wind lost income $\mathrm{I}_{22}$ & $\times 10^{8} \mathrm{RMB}$ \\
\hline & & & National power supply line loss ratio $\mathrm{I}_{23}$ & $\%$ \\
\hline & & & National electricity reliability $\mathrm{I}_{24}$ & $\%$ \\
\hline & & & National power supply per capita $\mathrm{I}_{25}$ & $\begin{array}{l}\text { kwh per } \\
\text { capita }\end{array}$ \\
\hline & & & National wind power industry jobs $\mathrm{I}_{26}$ & $\times 10^{4}$ units \\
\hline & & \multirow{3}{*}{$\begin{array}{l}\text { Reflection } \\
\mathrm{R}_{2}\end{array}$} & National total wind power investment $\mathrm{R}_{21}$ & $\times 10^{8} \mathrm{RMB}$ \\
\hline & & & Total investment in the construction of the national power grid $\mathrm{R}_{22}$ & $\times 10^{8} \mathrm{RMB}$ \\
\hline & & & National wind power policy $R_{23}$ & unit \\
\hline
\end{tabular}


on the environment, such as carbon dioxide, sulfur dioxide, oxynitride, and smoke dust emissions reductions and water resource and energy consumption (coal) savings. Reflection refers to the specific effective measures the government takes to promote wind power development.

In the sustainable wind power socioeconomic development subsystem, the driving forces are the background and needs of the socioeconomic wind power industry: national population, national GDP per capita, and national electricity consumption. Pressure reflects the potential wind power industry development risks and the consequent harm to society. For example, the national average abandoned wind ratio, which is an important index for wind power economic sustainability, can be affected if fans break down and cause electricity disruptions. The pressure results in a failure to provide sufficient capacity for grid acceptance. And wind power accidents can also reflect the safe and healthy development of the wind power industry. Situation is reflected in the effect of the wind power technological developments on the socioeconomic subsystem, with the national wind power industry installed capacity reflecting the development speed. The wind power industry generating capacity reflects the contribution wind power is making to clean energy optimization in the national energy generating plan. The national wind power integration ratio reflects the degree of coordination between the wind power industry and power transmission planning and construction. Influence refers to the influence of the wind power industry development on the national social economy, such as providing a people's livelihood services guarantee. For example, specified electricity consumption per capita, electricity reliability, and employment are a grantee. Besides, it can also include some harmful economic influences, such as the national wind abandoned electricity quantity and lost income. Reflection is the investment and positive policies implemented to encourage wind power industry development.

For some superior indices in the index system, such as the gross evaluated wind power energy, the gross developed wind power energy. The larger the index, the better, as these are all positively correlated with the system. As the indices increase, there is a commensurate increase in the socioeconomic benefits and an improvement in the environment. Conversely, abandoned wind lost income and national average wind abandoned ratio in the index system are the inferior indices. The smaller the index, the better, as these are negatively correlated with the system. As the indices reduce, the socioeconomic benefits increase and there is an improvement in the environmental benefits.

\section{Sustainable Wind Power Development Evaluation Method}

5.1. Evaluation Model. To evaluate the current level of Chinese wind power sustainability, an entropy weight TOPSIS evaluation method is used to quantize the subsystems. Mean square error is used to pretreat the indices to guarantee effectiveness and improve operations. Then, an entropy weight method is employed to confirm the weight of each index coefficient. The entropy weight and pretreated data are then combined, after which the TOPSIS method is used to determine and sort the data according to the similarity degrees, from which the evaluation results are derived. The evaluation model is shown in Figure 2.

5.2. Evaluation Steps. The route for researching technology is shown in Figure 3. The specific steps for the sustainable wind power development evaluation are as follows.

(1) Initial Data Pretreatment. The wind power initial data indices that have a negative effect on sustainable development are the inferior indices, and those that have a positive effect are the superior indices. In the process, it is necessary to transform the inferior indices into superior indices so the subsequent calculation can be made. To do this, the reciprocal method $(100 / \mathrm{x})$ on the absolute number of inferior indices and the difference method (1-x) on the relative number of inferior indices are employed to develop matrix $f_{i j}$. To eliminate the data dimensions and guarantee rationality, formula (1) is used to standardize and determine the standardized matrix value. A normalized decision matrix $Z^{\prime}$ is then built, the element for which is $Z_{i j}^{\prime}$,

$$
Z_{i j}^{\prime}=\frac{f_{i j}}{\sqrt{\sum_{i=1}^{n} f_{i j}^{2}}},
$$

$i=1,2 \ldots n ; j=1,2 \ldots m$.

(2) Determine the Weight of Each Index. $Z^{\prime}{ }_{i j}$ is the standard value for index $i$ in year $j, m$ is the number of evaluated years, and the unknown variable is $P_{i j}$,

$$
P_{i j}=\frac{Z_{i j}^{\prime}}{\sum_{j=1}^{m} Z_{i j}^{\prime}}
$$

Calculate the entropy $E_{i}$ for index i,

$$
E_{i}=-\frac{1}{\ln m} \sum_{j=1}^{m} P_{i j} \ln \left(P_{i j}\right)
$$

$W_{i}$ is the entropy weight for index $\mathrm{i}, \mathrm{m}$ is the number of evaluated years, and $W_{i}$ is the entropy weight for index I,

$$
W_{i}=\frac{1-E_{i}}{m-\sum_{i=1}^{m} E_{i}}
$$

(3) Determine Similarity Using the TOPSIS Method. (1) Build the normalized wind power weighted data matrix $\mathrm{Z}$ using the entropy weight from (4). Therefore, the element for the matrix is $Z_{i j}$,

$$
Z_{i j}=W_{i} Z_{i j}^{\prime}
$$

$i=1,2 \ldots n ; j=1,2 \ldots m$, and $W_{i}$ is weight of index $i$. 


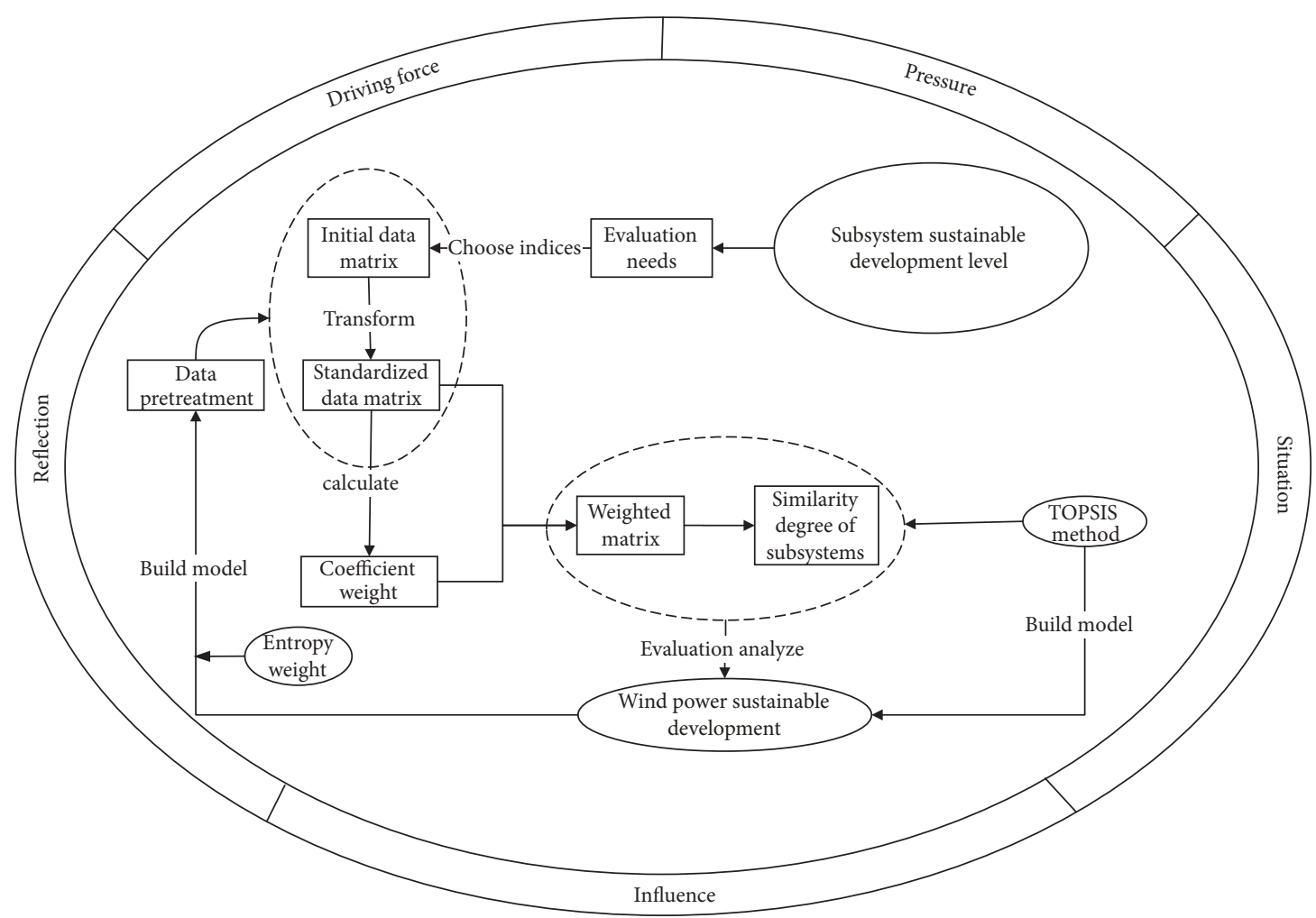

FIGURE 2: Sustainable wind power development evaluation model.

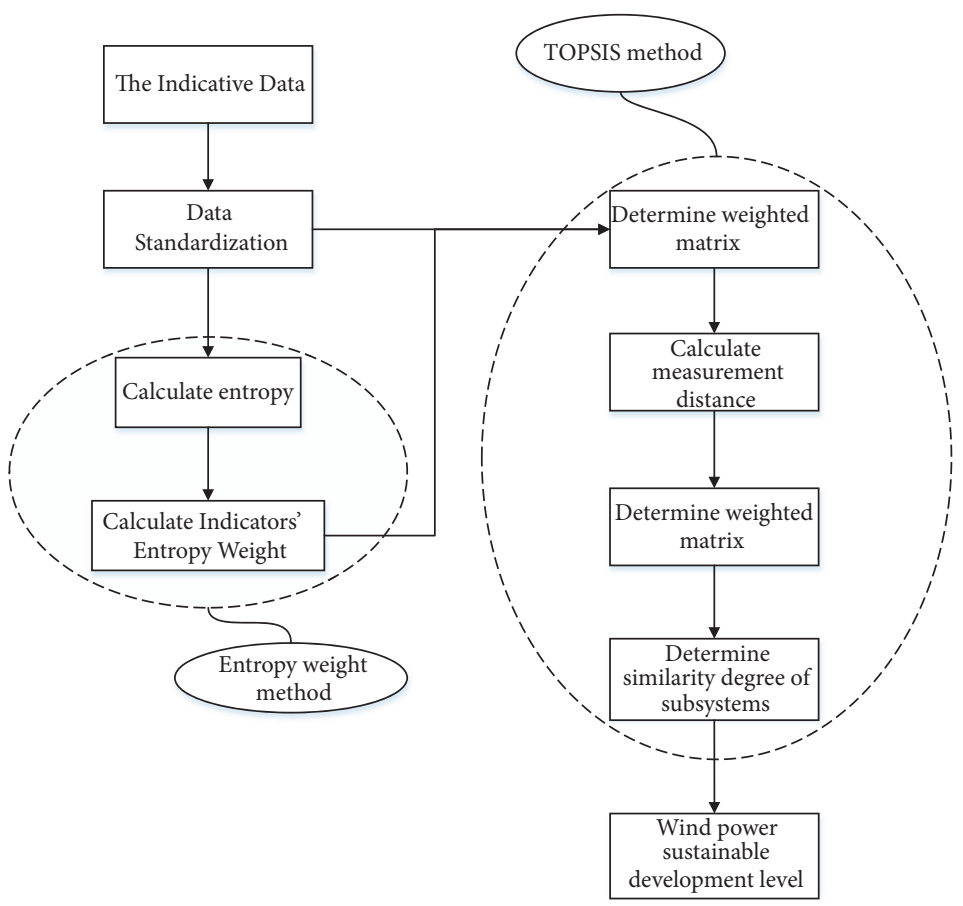

FIGURE 3: Sustainable wind power development evaluation steps. 


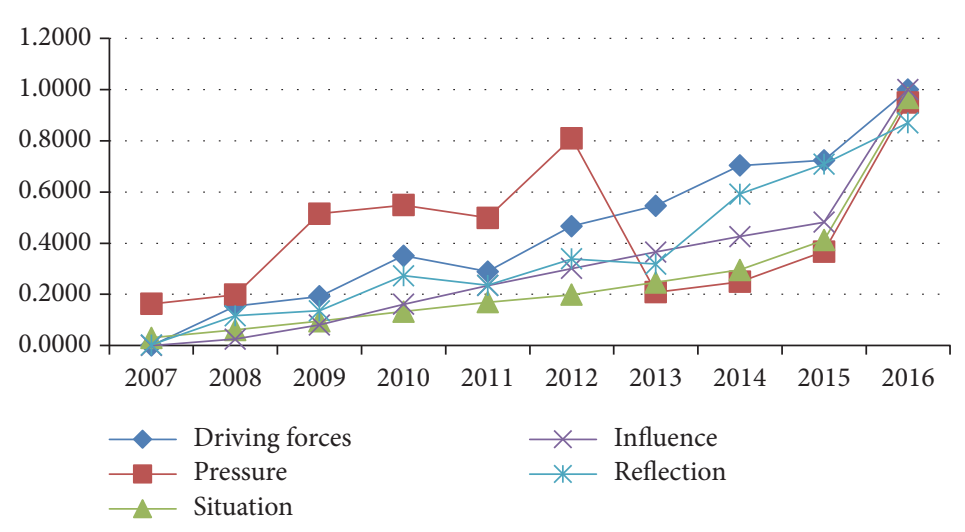

FIgURE 4: Sustainable Chinese environmental wind power development trend.

(2) Determine the positive ideal solution and the negative ideal solution for each index in each evaluated year.

$$
\begin{aligned}
& Z^{+}=\left(Z_{1}^{+}, Z_{2}^{+} \ldots Z_{m}^{+}\right)=\left\{\max _{i} Z_{i j} \mid j=1,2 \ldots m\right\} \\
& Z^{-}=\left(Z_{1}^{-}, Z_{2}^{-} \ldots Z_{m}^{-}\right)=\left\{\min _{i} Z_{i j} \mid j=1,2 \ldots m\right\}
\end{aligned}
$$

(3) Determine the Euclidean norm as the distance metric to calculate the distance from any feasible solution to the ideal solution for each index in each year.

$$
S_{i}^{+}=\sqrt{\sum_{j=1}^{m}\left(Z_{i j}-Z_{j}^{+}\right)^{2}}, \quad i=1,2 \ldots n
$$

where $Z_{i j}$ is the element for index $\mathrm{i}$, year $\mathrm{j}$, in the wind power weighted data matrix; similarly, the distance from any feasible solution $Z_{i j}$ to the negative ideal solution $Z^{-}$for each index in every year is

$$
S_{i}^{-}=\sqrt{\sum_{j=1}^{m}\left(Z_{i j}-Z_{j}^{-}\right)^{2}}, \quad i=1,2 \ldots n
$$

(4) The definition for the relative adjacent degree between the feasible solution in year $\mathrm{j}$ and the ideal solution in year $\mathrm{j}$ is

$$
C_{i}=\frac{S^{-}}{S^{-}+S^{+}}, \quad 0 \leq C_{i} \leq 1, \quad i=1,2 \ldots n
$$

The relative adjacent degree between the feasible solution and the ideal solution in year $\mathrm{j}$ is important as this is the sustainable wind power development evaluation level. The closer $Z_{i}$ is to the ideal solution, the closer $C_{i}$ is to 1 . Conversely, the closer $Z_{i}$ is to negative ideal solution, the closer $C_{i}$ is to 0 . By sorting $C_{i}$, the sustainable wind power development trend can be determined. And the level of every index i can be presented by $Z_{i j}$.

\section{Data and Results Analysis}

6.1. Data Analysis. The initial data for the index system were taken from the Statistical Yearbook of China, the National
Electricity Development Bulletin, the Statistical Yearbook, the Chinese Environment Statistical Yearbook of Chinese Energy, and the Statistical Yearbook of Chinese Electricity. The initial data were pretreated using formula (1), the weights of the subsystems calculated using formulas (2)-(4), and the weighted matrix determined using formula (5). The results are shown in Tables 2 and 3.

6.2. Result Analysis. (1) Tables 2 and 3 and Figures 4 and 6 show that Chinese sustainable environmental wind power development is fluctuating but generally has an upward trend.

From 2007 to 2016, the level of Chinese sustainable wind power development was rising. Based on the DPSIR model, the comprehensive analysis is as follows.

Overall, all driving forces affecting sustainable environmental wind power developments have risen. As the national economy has grown, there has been a commensurate rise in energy consumption. The development and utilization of new energy sources such as wind power have been steadily increasing, meaning that there is a greater proportion of nonfossil fuel being harnessed to meet primary energy demand. In September 2009, the Chinese government announced that the proportion of nonfossil fuel in primary energy was expected to exceed $15 \%$ by 2020 [21].

To conserve energy and reduce or eliminate emissions, it is also necessary to change energy production structures and guarantee energy safety for the future. Facing these challenges, the Chinese government has promulgated policies to encourage the development of new, clean energy sources, and reduce fossil fuel related emissions. Thus, the pressure on sustainable environmental wind power development has been slowly declining. Situationally, over 4 billion kilowatt hours of wind power energy is now being produced with the possibility of significantly increased capacity in the future. As wind power energy technology developed and the government placed more weight on the wind power industry, the evaluated and developable gross increased, resulting in improvements in sustainable environmental wind power development. Because of the increasing capacity in the Chinese wind power industry, from 2007 to 2015, 282.87 million tons of coal was saved, which equated to reductions of 75.87 billion tons of carbon dioxide, 19.401 million tons 


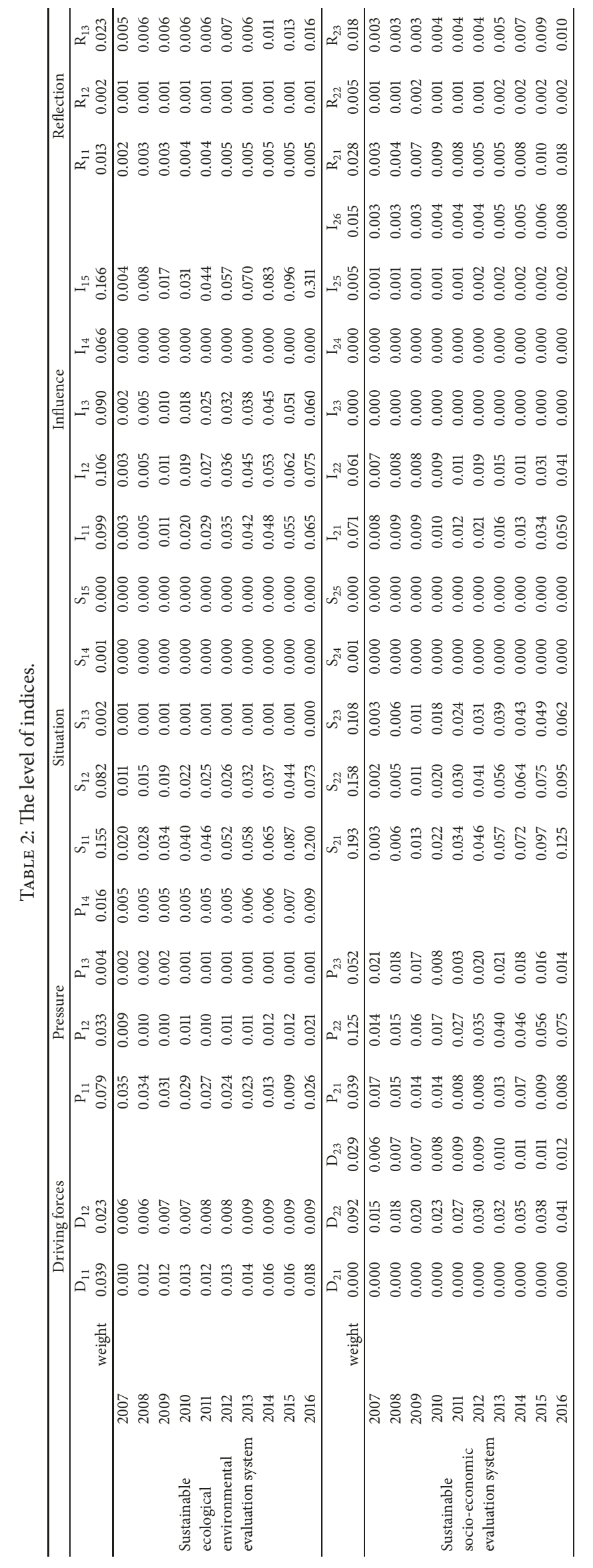


TABLE 3: Chinese sustainable wind power development evaluation table.

\begin{tabular}{lccc}
\hline Year & Ecological environmental level & Socio-economic level & Sustainable development level \\
\hline 2007 & 0.117 & 0.175 & 0.096 \\
\hline 2008 & 0.121 & 0.177 & 0.089 \\
\hline 2009 & 0.137 & 0.179 & 0.117 \\
\hline 2010 & 0.316 & 0.213 & 0.172 \\
\hline 2011 & 0.245 & 0.249 & 0.267 \\
\hline 2012 & 0.308 & 0.299 & 0.389 \\
\hline 2013 & 0.370 & 0.351 & 0.479 \\
\hline 2014 & 0.425 & 0.398 & 0.267 \\
\hline 2015 & 0.505 & 0.458 & 0.749 \\
\hline 2016 & 0.955 & 0.926 & 0.942 \\
\hline
\end{tabular}

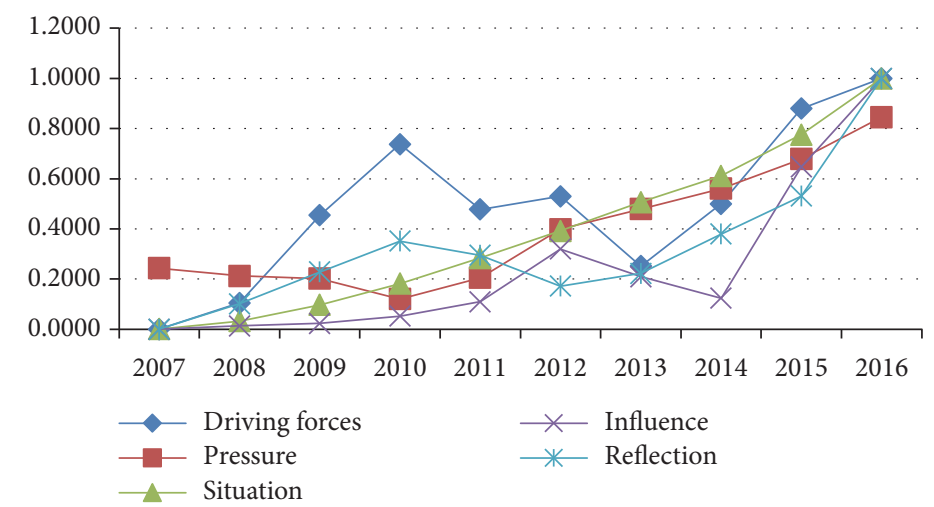

Figure 5: Sustainable Chinese socioeconomic wind power development trend.

of sulfur dioxide, and 21.332 million tons of oxynitride [22]. Further, as the Chinese government has placed increased focus on environmental protection and improvement, the proportion of environmental investment as a percentage of GDP has risen from $1.2 \%$ to $1.9 \%$. So, reflection on sustainable environmental wind power development has been rising.

Wind power can be a major force in achieving China's low-carbon energy strategy and the development of renewable energy. Therefore, it is expected that sustainable environmental wind power industry development will be further improved.

(2) From an analysis of the data changes in Tables 2and 3 and Figures 5 and 6, it can be seen that the Chinese sustainable socioeconomic wind power development level is steady and making progress, although the growth rate is moderating.

From 2007 to 2016, the overall socioeconomic sustainability level of Chinese wind power was rising. Although it reached a low point in 2014, there was a great improvement from 2014 to 2016. Overall, the rapid development of the wind power industry has had an increasing function in meeting electricity demand, optimizing the energy structure, supporting the national economy, and contributing to social development.

From the DPSIR model, the effect of the sustainable wind power development on the socioeconomic situation changed during the sample years. When viewed through the lens of the driving forces, as the economy developed, the population and the demand for power grew. Therefore, the sustainable socioeconomic wind power development driving forces increased, while the pressure on wind power sustainability was reducing, due to government intervention and state regulation to avoid national electricity accidents and reduce the time the wind turbines were offline. In recent years, wind power industry development has suffered from a high wind abandoned rate (up to $16.2 \%$ in 2011 and $17.1 \%$ in 2012) because of insufficient consumption ability, peaking difficulties, and limited channels [23]. The pressure driving force on sustainable socioeconomic wind power development has therefore been increasing, but the growth rate is moderating. The pressure in 2010 was temporarily reduced because of an accident.

For the situation driving force, the Chinese wind power industry entered a rapid development stage after 2006, with annual new installation in the world increasing from less than $10 \%$ in 2006 to $49 \%$ in 2010 . By the end of 2010 , the Chinese wind power grid operating installed capacity was 31 million kilowatt, and, by the end of 2016, it had reached 163 million kilowatt. The Chinese national wind power generating capacity was 50 billion kilowatt hours in 2010 , accounting for $1.2 \%$ of total generating capacity. By 2016, this had increased to 231.4 billion kilowatt hours [24, 25]. Therefore, stable growth in the sustainable socioeconomic wind power development situation was confirmed. The major 


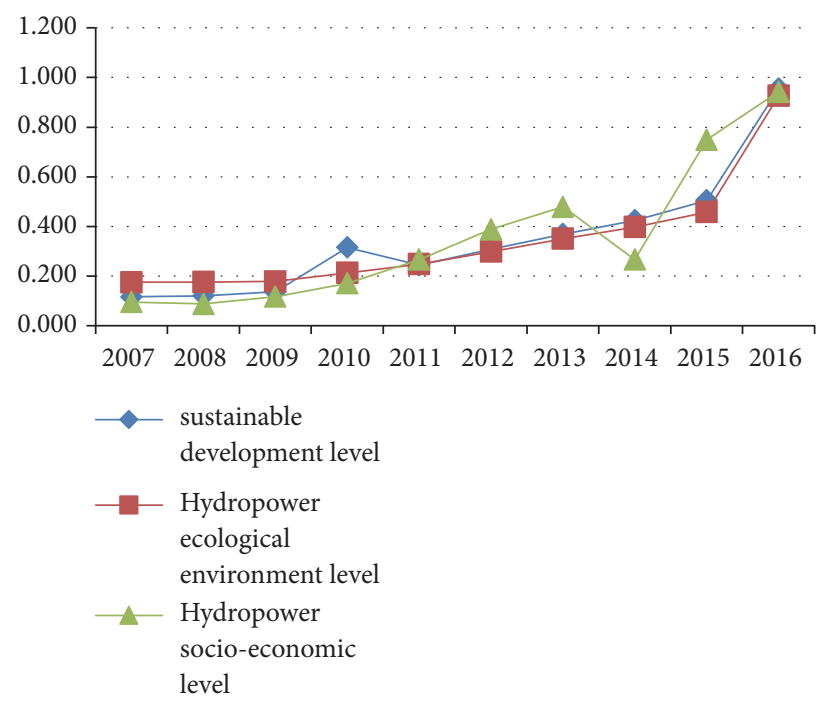

Figure 6: Sustainable Chinese wind power development trend.

influence observed was the high wind abandoned rate, which resulted in a large amount of abandoned electricity and significant lost income, causing a downward trend in the influence driving factor. The wind abandoned rate reached a peak in 2012, with the situation moderating in 2013 and 2014 and the influence slightly rising. However, the wind abandoned rate increased again, causing the influence to decline. Although wind power is rapidly developing, the related consumption and support systems are incomplete, with the "large quantity, low efficiency" problems in urgent need of solutions.

With continuous investment in wind power projects and continuous improvements in related policies, the reflection driving force has risen. In 2010, total investment reached 103.8 billion RMB. However, in 2011 and 2012, the investment (and the reflection) slightly declined as there were further improvements in wind power infrastructure. After 2013, the government invested heavily again in the construction of wind power energy equipment, in an effort to resolve the abandoned wind problem. Wind power is safe, clean, economical, and efficient and therefore has strategic significance in energy production and usage reforms as it can contribute to the development of a safe, stable, economical, clean, modern energy system and guarantee sustainable socioeconomic development $[24,25]$. The wind power industry needs to consider the system's economy and comprehensive energy consumption, improve quality and efficiency, enter a stage of stable and orderly growth using national policies and market forces, and improve the sustainable development level.

(3) From Figure 6, we can find that Chinese sustainable wind power development is rising.

Under the common influence of the socioeconomic wind power subsystem and the ecological environmental wind power subsystem, the overall level of sustainable wind power development is expected to continue to increase. China has good wind energy conditions, abundant, wide land resources, a mature wind power industry foundation, the support of a widespread grid, and advanced technology, all of which means that China has the capacity to develop a large scale wind power network. In recent years, based on calculated measures such as the different electrovalence in different areas, cost allocations, and grid priorities, the government has successively issued the "Renewable Energy Law", the "12th Five-Year Plan for Energy", and the "12th Five-Year Plan for Wind Power" and developed a comprehensive policy system to promote the development of wind power and organized wind power evaluations, wind power concession project bidding, and marine wind power demonstration project construction.

Wind power industry development strength has been rapidly improving and the market scale continuously extending [26]. China's installed wind capacity is predicted to add up to 400 million kilowatts to the national grid by 2030, with the generating capacity proportion expected to rise to $8.4 \%$ and the power source structure proportion predicted to rise to $15 \%$. The industrial concentration in the Chinese wind power manufacturing industry has also been improving; as more wind power supporting industries develop, the wind power industry chain is becoming more complete. Therefore, with government support and healthy wind power equipment manufacturing industry growth, wind power's core competitiveness is growing.

What is more, from Table 2, it can be found that the driving force of each subsystem has not changed much in the wind power industry. However, national nonfossil fuel energy consumption accounts for primary energy and national energy consumption in ecological environmental evaluation system is much more. Obviously, national carbon dioxide emissions of pressure in ecological environmental evaluation system has a sharp drop. Pressure in socioeconomic evaluation system has smaller fluctuations. In the aspect of situation, gross evaluation and gross development national wind power energy increase year by year, and national abandoned wind electricity, national abandoned wind lost income, and national power supply line loss ratio have similar trend. It also can be seen that the influence of wind power 
industry on ecological environment is far greater than that on social economy. Meanwhile, the reflection degree of the two subsystems to the development of wind power industry is basically the same.

\section{Conclusion}

China's wind power industry is entering a comprehensive and rapid new development stage. However, as the proportion of wind power is lower comparing to conventional energy generation, the full development potential has not yet been attained, and there are still problems that need to be resolved such as abandoned wind brownouts. In the following, several wind power development proposals are given.

First, at the macrolevel wind power in China is predicted to reach 200 GW by 2020 (IEA World Energy Outlook, 2016), so it is already a very mature technology. And subsidies should be phased out through time. However wind power prices are high and there is no competitive advantage. It is necessary that the government needs to gradually undercut the wind power on-grid price and build a timely subsidy settlement mechanism based on a "smart energy" Internet platform for the distribution of renewable energy during "13th Five-Year" Plan [27]. At the same time, a coordinated preferential income tax policy is also formulated [28].

Second, on the industry level, overall planning needs to be strengthened by coordinating grid construction. It includes adding wind power construction to grid construction planning, planning main net frame construction ahead of time, building ultrahigh voltage direct current delivery channels in the three northern areas, and building a recycling mechanism for the transmission channel system operating costs. Improvements are also needed for the inner consumption ability in the three northern areas, and smart grid construction is also needed to improve basic infrastructure and grid scheduling. To reduce passive fan fault repair rates and optimize generation, operation, repairs, and asset management at wind farms, meteorological data could be combined with wind farm siting and fan selection using big data.

Finally, at the micro- or enterprise level, technological progress needs to be promoted to reduce development costs. Due to weak research into and development of core technologies and the lack of development experience, there remains a development and utilization efficiency gap between China and more developed countries. For example, while China's cumulative installed wind power was twice that of the United States in 2016, its wind power generating capacity was 241 billion kilowatt hours compared to the US 224 billion kilowatt hours. Therefore, wind power energy development costs need to be reduced through comprehensive research. The link between wind energy development enterprises, equipment manufacturers, engineering services, and grid enterprises need to be strengthened to provide technological support for improving independent innovation and whole industry capacity. Therefore, enterprises could be involved in developing advanced wind power talents through collaborations with colleges and universities, the developing of specific wind power education and training bases and postdoctoral research stations, and harnessing international talent.

This paper developed a comprehensive Chinese sustainable wind power development evaluation index system based on the DPSIR model, after which the entropy weight and TOPSIS methods were used to conduct quantitative research into China's sustainable socioeconomic and ecological environment wind power development on data from 2007 to 2015, from which the following specific research conclusions were drawn.

(1) Based on the DPSIR model, a scientific, systematic, quantized sustainable development index system was developed that clearly reflected the external environment of Chinese wind power industry development and socioeconomic environmental coordination degree, all of which provided theoretical support for a quantitative evaluation of Chinese sustainable wind power development.

(2) A Chinese wind power sustainable development evaluation model was built based on real data and a measurement and judgement analysis conducted on the sustainability of the socioeconomic and ecological wind power environments. A systematic evaluation of the actual wind power situation in China was conducted, with the results being found to be rational and objective, thereby verifying the effectiveness of the built model.

(3) The macroinfluences on China's wind power sustainable development were identified, which provide valuable evaluation evidence for wind power industry managers. The quantitative evaluation of China's sustainable wind power development also highlighted the current weaknesses. Therefore, it is recommended that the current socioeconomic environmental index system be refined to focus more on evaluation rather than being a policy guide.

In conclusion, in this paper, a sustainable wind power development model was built based on the entropy weight and TOPSIS methods. However, as this model was only able to analyze the macrotrends and development levels, rather than reflecting the DPSIR model logical relationships, in future research, it is intended to build a complete evaluation system across multiple dimensions to fully identify the logical relationships between the indices, all of which would increase the theoretical contribution and add to the model's practical value.

\section{Data Availability}

The data used to support the findings of this study are available from the corresponding author upon request.

\section{Conflicts of Interest}

The authors declare no conflicts of interest.

\section{Acknowledgments}

This work is supported by the National Nature Science Foundation of China (71601134), 2017 Social Science "Thirteen Five-Year" Plan Annual Projects in Sichuan 
Province (SC17TJ010), Foundation of Sichuan University (skyb201709).

\section{Supplementary Materials}

The original data in the article are included in the supplementary materials. (Supplementary Materials)

\section{References}

[1] U. Nations, "Earth Summit Agenda 21. The United Nations programme of action from Rio," 1992.

[2] J. Liu and T. S. Liu, "Promote wind power construction, develop renewable energy," Environment and Development, vol. 22, no. 5, pp. 4-5, 2010.

[3] X. F. Liu and X. Liang, "Pros and cons analysis and countermeasures of new energy development in Fujian province," China Urban Economy, no. 20, pp. 26-27, 2011.

[4] D. R. C. National, "Chinese Wind Power Development Route Map 2050," Energy Research Institute, 2011.

[5] Q. P. Zhao and P. Liu, "Economic sustainable development from our energy structure with coal majority," The Fourth Cross-Strait Applied Statistics Seminar in 2008, 2010.

[6] Z. Q. Zhang, G. D. Cheng, and Z. M. Xu, "Sustainable Development Assessment Indicators, Methods and Applications," Journal of Glaciology and Geocryology, vol. 24, no. 4, pp. 344460, 2011.

[7] P. Pinson and G. N. Kariniotakis, "Wind power forecasting using fuzzy neural networks enhanced with on-line prediction risk assessment," in Proceedings of the 2003 IEEE Bologna Power Tech Conference, vol. 2, pp. 64-72, Bologna, Italy, June 2003.

[8] W. Deng, H. Ding, B. Zhang, X. N. Lin, P. Bie, and J. Wu, "Multi-period probabilistic-scenario risk assessment of power system in wind power uncertain environment," Iet Generation Transmission \& Distribution, vol. 10, no. 2, pp. 359-365, 2016.

[9] J. Li and Y. S. Sun, The application of fuzzy net analysis in overseas wind power projects risk evaluation, Dalian University of Technology, 2008.

[10] C. Jiang, W. X. Liu, and J. H. Zhang, "The risk evaluation of composite generation and transmission systems including wind power integration," Transactions of China Electrotechnical Society, vol. 29, no. 2, pp. 260-270, 2014.

[11] A. C. N. Salles, A. C. G. Melo, and L. F. L. Legey, "Risk analysis methodologies for financial evaluation of wind energy power generation projects in the Brazilian system," in Proceedings of the 2004 International Conference on Probabilistic Methods Applied to Power Systems, pp. 457-462, September 2004.

[12] P. Y. Zhan, "The financial evaluation method and application research of wind power projects," International Economic Cooperation, vol. 6, pp. 64-66, 2011.

[13] T. Shiau and J. Chuen-Yu, "Developing an Indicator System for Measuring the Social Sustainability of Offshore Wind Power Farms," Sustainability, vol. 8, no. 5, pp. 470-483, 2016.

[14] E. C. D. Organization and S. E. Group, "OECD core set of indicators for environmental performance reviews," Environment Monographs, 1993.

[15] R. C. Edward, "Applying DPSIR to sustainable development," International Journal of Sustainable Development \& World Ecology, vol. 14, no. 6, pp. 543-555, 2007.
[16] D. W. Cash, W. C. Clark, F. Alcock et al., "Knowledge systems for sustainable development," Proceedings of the National Acadamy of Sciences of the United States of America, vol. 100, no. 14, pp. 80-86, 2003.

[17] T. Hák, S. Janoušková, and B. Moldan, "Sustainable Development Goals: A need for relevant indicators," Ecological Indicators, vol. 60, pp. 565-573, 2016.

[18] Z. Q. Zhang and C. Q. Sun, "Sustainable development research: progress and trend," Advance in Earth Sciences, vol. 14, no. 6, pp. 589-595, 1999.

[19] Q. Cao, X. P. Chen, and M. J. Shi, "Evaluation of water resources security in the urban area and regulating methods based on dpsir: a case of zhangye city," Resources Science, vol. 34, no. 8, pp. 1591-1599, 2012.

[20] Y. Z. Li, Y. Liu, and X. P. Yan, "The evaluation index system research of watershed ecology safety based on DPSIR model," Acta Scientiarum Naturalium Universität's Pekinensis (Nature Sciences), vol. 48, no. 6, pp. 971-981, 2012.

[21] L. Cheng, L. P. Jiang, and J. H. Bai, "The route research to achieve goal of 15\% non-fossil fuel by 2020," China Energy, vol. 32, no. 8, pp. 9-12, 2010.

[22] Y. C. Huang, M. Li, Y. N. Wang, and R. Zhang, "The environmental economic benefits analysis of wind power energy conservation and emission reduction," China Market, vol. 24, pp. 135-139, 2014.

[23] Q. K. Wang, "Wind abandoned situation and experience analysis at home and abroad," East China Electric Power, vol. 3, pp. 378-381, 2012.

[24] E. A. National, "The Thirteenth Five-year Plan of Wind Power," 2016.

[25] C. State, "The Twelfth Five-year Plan of Energy Development," 2013.

[26] H. Y. Qin, "Promote our wind power international cooperation in multi-channel," Wind Power, vol. 10, 2015.

[27] R. I. Energy, The Instruction about Promoting Internet plus Smart Energy Development, National Development and Reform Commission, 2011.

[28] G. P. Yao, Y. F. Yue, and Z. Z. Wang, "Analysis and policy Suggestions on macro-obstacles of China's wind power development," Electric Power Construction, vol. 24, no. 12, pp. 29-31, 2003. 


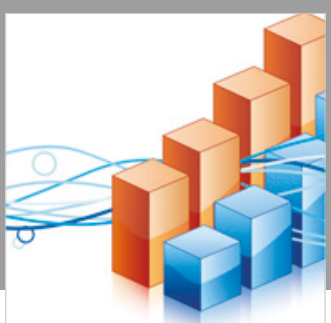

Advances in

Operations Research

\section{-n-m}
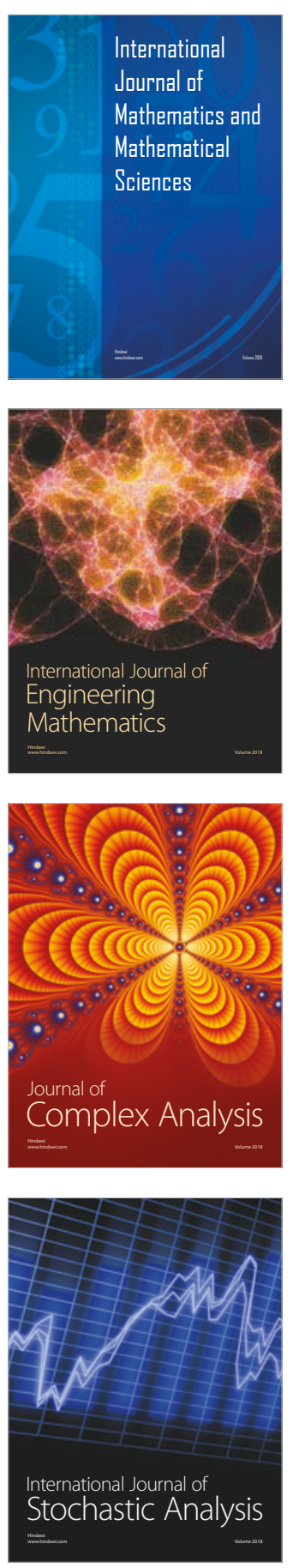
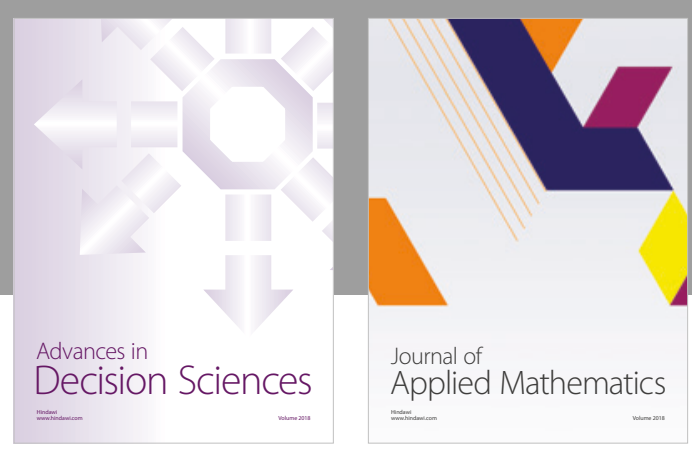

Journal of

Applied Mathematics
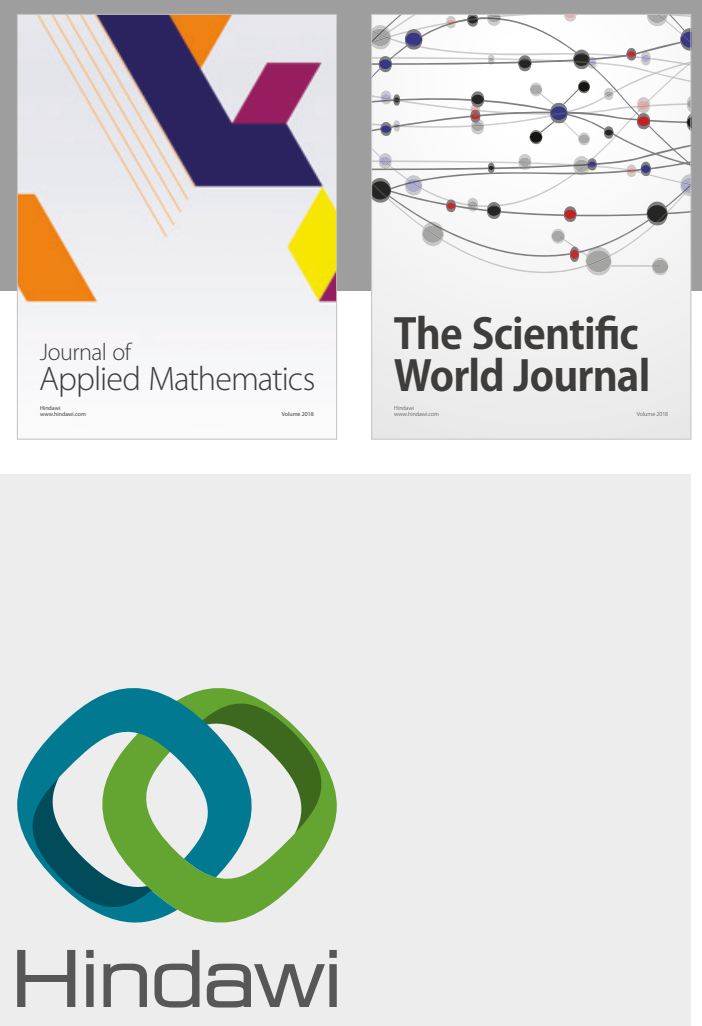

Submit your manuscripts at

www.hindawi.com

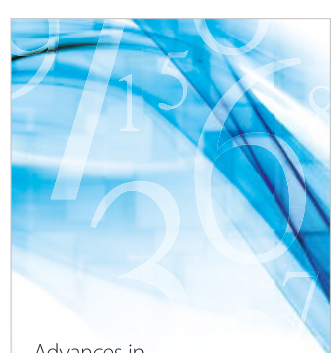

Advances in
Numerical Analysis
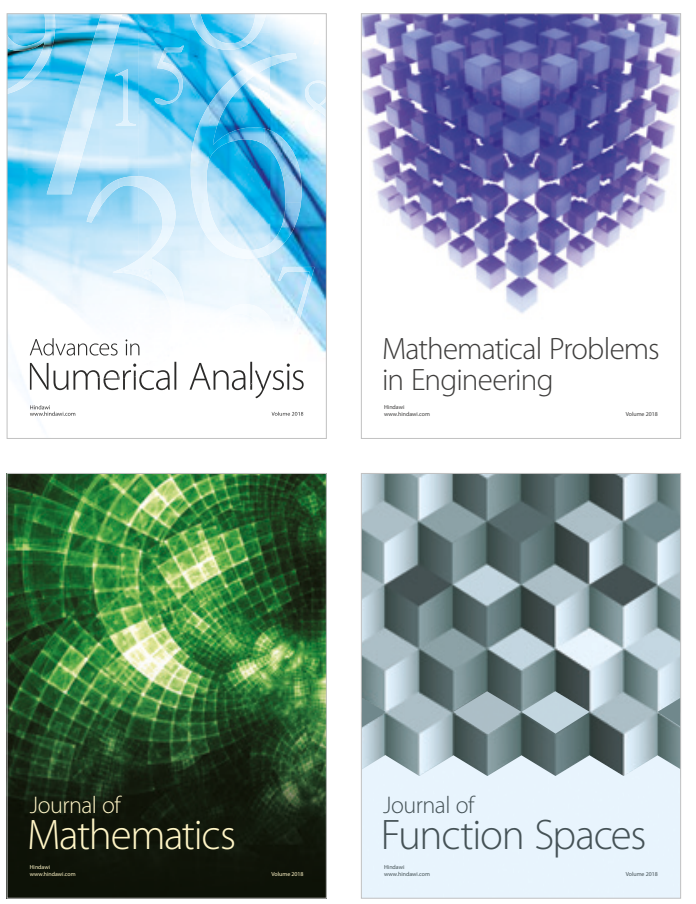

Mathematical Problems in Engineering

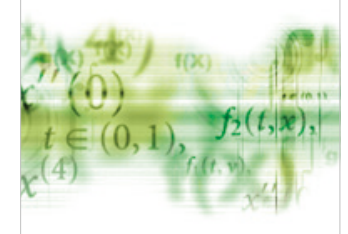

International Journal of

Differential Equations

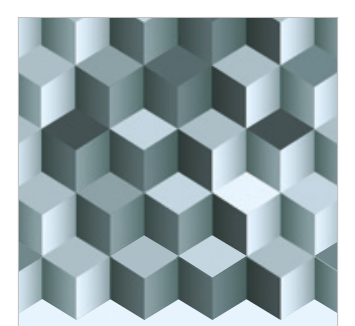

Journal of

Function Spaces

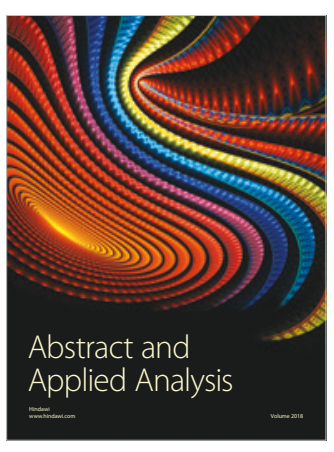

The Scientific

World Journal

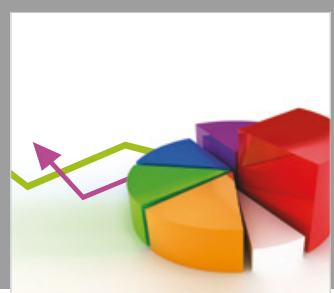

Journal of

Probability and Statistics
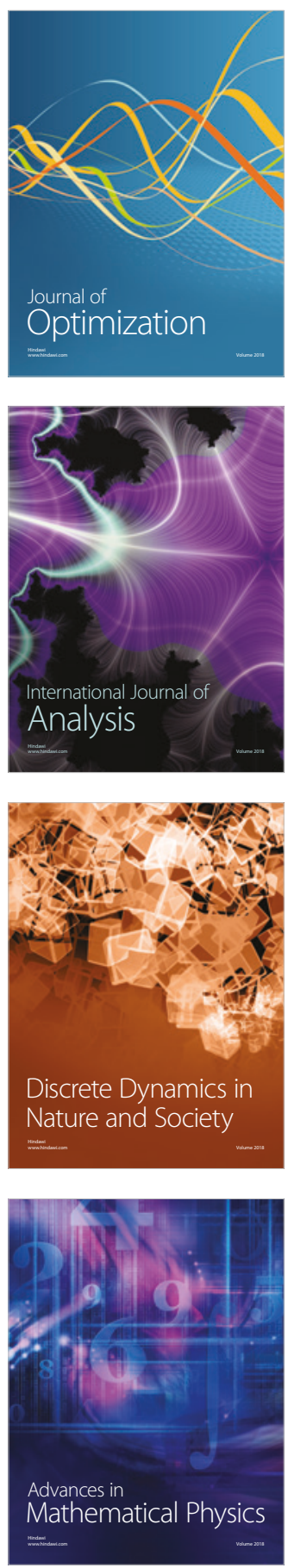